\title{
Editorial \\ Methicillin-Resistant Staphylococci and Macrococci at the Interface of Human and Animal Health
}

\author{
Karsten Becker (D)
}

check for updates

Citation: Becker, $\mathrm{K}$.

Methicillin-Resistant Staphylococci and Macrococci at the Interface of Human and Animal Health. Toxins 2021, 13, 61. https://doi.org/ $10.3390 /$ toxins 13010061

Received: 8 January 2021 Accepted: 11 January 2021 Published: 14 January 2021

Publisher's Note: MDPI stays neutral with regard to jurisdictional clai$\mathrm{ms}$ in published maps and institutional affiliations.

Copyright: (C) 2021 by the author. Licensee MDPI, Basel, Switzerland. This article is an open access article distributed under the terms and conditions of the Creative Commons Attribution (CC BY) license (https:// creativecommons.org/licenses/by/ $4.0 /)$.
Friedrich Loeffler-Institute of Medical Microbiology, University Medicine Greifswald, 17475 Greifswald, Germany; karsten.becker@med.uni-greifswald.de

The global impact of methicillin-resistant Staphylococcus aureus (MRSA) clonal lineages on human and animal health continues, even considering the decreasing MRSA rates in some parts of the world [1,2]. Subsequent to the emergence of hospital-associated (HA) and community-associated (CA) MRSA, livestock-associated (LA) MRSA has become an additional threat for human and animal health, contributing significantly to morbidity, mortality and socio-economic costs [3-5]. Linking human, animal and environmental health, the basically old - but for a long time too little considered - holistic "One Health" concept is more imperative than ever to solve the challenges due to microorganisms which cross the boundaries of ecosystems [6].

Many aspects of the genetic basis, origin, distribution, transmission, virulence profile and introduction into the health care systems of MRSA are still poorly understood. The genetic basis of their almost complete resistance to $\beta$-lactam antibiotics, the staphylococcal cassette chromosome mec (SCCmec), has been characterized as large mobile genetic elements harboring not only the methicillin resistance-encoding genes but also genes mediating resistance towards other antibiotics, heavy metals and metalloids. This co-possession may lead to co-selection effects [7-9] that can negatively influence MRSA prevention efforts, for example, in husbandry [10].

The continued detection of novel SCCmec types and subtypes, as well as the recent expansion of the mec "alphabet" by the detection of the mecC, mecB and mecD genes, reflects the flexibility of staphylococci and their relatives, the macrococci, to resist the selection pressures occurring in their environment, [11-13]. The identification of plasmidborne methicillin resistance in macrococci and staphylococci adds further to the enormous complexity of the genetic organization of methicillin resistance in the Staphylococcaceae family [14-16]. Thus, MRSA are not to be understood monolithically. This huge diversity and the ongoing dynamics of the distribution of their clonal lineages [17] is challenging culturebased and molecular routine diagnostics, as well as epidemiological studies. Moreover, the impact of coagulase-negative staphylococci and coagulase-positive non-S. aureus complex species, as well as the role of macrococci as source for methicillin resistance-encoding genetic elements in $S$. aureus are only scantily investigated. The impact of virulence factors, particularly toxins, on the adaptation of Staphylococcaceae members to novel hosts and/or ecosystems is also widely unknown.

Focusing on methicillin resistance and toxins in Staphylococcaceae, the aim of this Special Issue, "Methicillin-Resistant Staphylococci and Macrococci at the Interface of Human and Animal Health", was to gather data on basic, epidemiological, ecological and medical aspects on the interface between animal keeping, wildlife and putative other niches on one hand, and human and animal health on the other.

Livestock-associated (LA) MRSA belonging to Clonal Complex (CC) 398 are a prime example of an emerging clonal lineage that leads to significant burden for the human health care system after overcoming the host species barrier and becoming a zoonotic pathogen $[3,4,18,19]$. Especially in areas with a high density of pig farming, LA-MRSA isolates account for a substantial proportion (up to $30 \%$ or more) of all MRSA recovered 
from patients in those regions, even from patients with sepsis or other invasive infections [20-22]. The introduction of LA-MRSA, particularly CC398 isolates, into hospitals occurs via patients with occupational livestock exposure [23-25]. Here, Cuny et al. report on their cross-sectional study, which has been performed to answer the question whether those with occupational exposure to raw meat and to raw meat products are at particular risk of nasal colonization by LA-MRSA [26]. While reports on contamination of raw meat by LA-MRSA have been published [27,28], the occupational handling of raw meat was not found to be associated with the acquisition of LA-MRSA, as was examined in the investigation of nasal swabs from more than 600 butchers and cooks [26]. The authors concluded that, probably, the general population may be at an even lower risk of acquiring LA-MRSA via raw meat contact, particularly if good kitchen hygiene practice is followed.

Ribeiro et al. [29] have analyzed another putative risk factor for the acquisition of methicillin-resistant staphylococci (MR-S), i.e., unpasteurized milk used in the production of artisanal cheeses. Their study, comprising five Brazilian dairy farms, indicated crosscontaminations with MR-S during cheese production. Thus, employees working in milking and artisanal unpasteurized cheese production could contribute to the dissemination of MR-S species through incorrect product handling procedures.

At the beginning of the emergence of the novel LA-MRSA clonal lineages, their virulence and capacity to cause severe infections were questioned [3,30]. In this issue, Treffon et al. [31] address the virulence potential of LA-MRSA CC398 recovered from respiratory specimens of cystic fibrosis (CF) patients in comparison with hospital-associated (HA) MRSA and methicillin-susceptible S. aureus (MSSA) strains. CF patients are characterized by reduced lung function and life expectancy due to chronic bacterial airway infections, notoriously by $S$. aureus. The authors observed that LA-MRSA strains from CF patients were strongly hemolytic and more cytotoxic than HA-MRSA strains. The LA-MRSA strains were shown to be also more invasive than the MSSA isolates tested [31]. Of interest, their investigations also confirmed for LA-MRSA that that the adaptation of $S$. aureus to $\mathrm{CF}$ airways is an individual and very complex process which might hamper the success of anti-staphylococcal treatment of respiratory infections of this patient population.

From a basic clinical point of view, one could say that "an S. aureus is an S. aureus is an S. aureus," which means that almost every S. aureus strain is able to cause the wide range of pyogenic infections for which this pathogen is notorious. However, some strains are "special" in the sense that they possess additional virulence factors, which are not part of the $S$. aureus core genome. These include isolates that possess specific toxins, such as the classical and newly described pyrogenic toxin superantigens (PTSAgs), and also single members of the synergohymenotropic toxin family, such as the Pantone-Valentine leucocidin (PVL). PVL-possessing isolates are frequently associated with skin and softtissue infections and can also cause a special, severe entity of pneumonia described as necrotic hemorrhagic pneumonia [32]. Mairi et al. [33] collected more than 2000 samples from humans, livestock, wild and companion animals, food products and the aquatic environment to study the distribution of MSSA and MRSA isolates in different ecological niches in Algeria and to determine the occurrence the prevalence of PVL gene-positive isolates. Of note, $10.6 \%$ of the detected S. aureus isolates tested positive for PVL and some of these co-harbored other toxin genes, such as exfoliative toxins or PTSAgs. All PVL-positive MRSA isolates belonged to the ST80-IV CA-MRSA clonal lineage. In contrast, PVL-positive MSSA isolates emerged from different sources. Another main finding of this study was the high prevalence of toxinogenic MSSA strains, mainly due to strains carrying the toxic shock toxin-1 (TSST-1) gene. Again, high genotypic diversity was found for strains tested positive for the TSST-1-encoding gene.

While MRSA-ST80, mostly represented by spa type t044, has become known as the predominant human CA-MRSA lineage throughout Europe, Northern Africa and the Middle East, food- and animal-associated isolates are rare. In a second article in this issue, Mairi et al. [34] summarize reports about positive MRSA-ST80 isolates in farm and wild animals and other ecological niches such as food. In their systematic review comprising 
PubMed-catalogued papers ( $n>100$ ) from 2003 to 2019, they found that, at least for this known PVL-positive lineage, the overall proportion has decreased in many countries in recent years.

Scholtzek et al. [35] characterized equine S. aureus isolates that show elevated minimal inhibitory concentrations (MICs) for oxacillin but could not be categorized as MRSA. Those so-called borderline oxacillin-resistant $S$. aureus (BORSA) strains pose a challenge for routine laboratories in both human and veterinary medicine if no special procedures and molecular confirmation are practiced. The term BORSA comprises a heterogeneous group of mostly weak oxacillin- or methicillin-resistant staphylococcal isolates that are still poorly understood and inadequately defined [36]. They have in common that they miss any kind of mec genes; thus, the additional penicillin-binding protein (PBP) PBP2a is not formed. Instead, they are characterized by hyper-production of beta-lactamases or their resistance is associated with point mutations of the PBPs occurring usually in S. aureus. By core genome multilocus sequence typing, Scholtzek et al. observed the close relatedness of the isolates belonging to either ST1 or ST1660 [35]. The beta-lactamase activity of the 19 isolates included was found to be associated with an inducible blaZ gene.

It is a truism that proper selection of the breeding line of an experimental animal and also their colonization status (microbiota) may drastically influence the outcome of a given experiment. Raafat et al. [37] report on their investigations into the molecular epidemiology of MSSA and MRSA in laboratory rats including both Rattus norvegicus and Rattus rattus. These investigations are of importance because rats can also serve as a reservoir for MSSA as well as HA- and LA-MRSA and other MR-S [38-40]. In a comparison of the colonization of laboratory rats with the composition of the natural S. aureus population in wild and captive rats, significant differences between the different populations were detected. While the natural S. aureus population of wild rats comprised mainly CC49- and CC130-MSSA strains, laboratory rats showed a lower nasal S. aureus carriage rate but were colonized with many different, mostly typically human-associated, S. aureus lineages. Common LA-MRSA (spa type t011) and other animal-associated MRSA lineages (CC30 and CC130) were found in wild and captive rats. The CC130 isolates possessed the mecC gene instead of mecA.

Since certain S. aureus lineages reveal substantial zoonotic potential, effective "One Health" concepts against the spread of MRSA have to take transmissions among farm animals, and also companion and wild animals and humans, into account. Especially, measures need to be intensified (i) to lower the resistance selection pressure by reducing consumption of antibiotics and co-selecting agents (e.g., metals as food supplements), (ii) to reduce the transmission of pathogens between animals and humans in husbandry by improving basic hygiene and (iii) to improve the surveillance of multi-resistant organisms.

Funding: This work was funded in part by the Federal Ministry of Education and Research (BMBF), grant number 01KI1727A.

Acknowledgments: The editors are grateful to all the authors who contributed to this Special Issue, "Methicillin-Resistant Staphylococci and Macrococci at the Interface of Human and Animal Health". Special thanks to the peer reviewers for their expert evaluations, which have contributed to increasing the quality of the research works and reviews compiled in this Special Issue. Finally, we thank the MDPI management team and staff for their valuable contributions, organization and editorial support.

Conflicts of Interest: The author declares no conflict of interest.

\section{References}

1. Lee, A.S.; de Lencastre, H.; Garau, J.; Kluytmans, J.; Malhotra-Kumar, S.; Peschel, A.; Harbarth, S. Methicillin-resistant Staphylococcus aureus. Nat. Rev. Dis. Primers 2018, 4, 18033. [CrossRef]

2. Köck, R.; Becker, K.; Cookson, B.; van Gemert-Pijnen, J.E.; Harbarth, S.; Kluytmans, J.; Mielke, M.; Peters, G.; Skov, R.L.; Struelens, M.J.; et al. Methicillin-resistant Staphylococcus aureus (MRSA): Burden of disease and control challenges in Europe. Euro Surveill. 2010, 15, 19688. [CrossRef]

3. Becker, K.; Ballhausen, B.; Kahl, B.C.; Köck, R. The clinical impact of livestock-associated methicillin-resistant Staphylococcus aureus of the clonal complex 398 for humans. Vet. Microbiol. 2017, 200, 33-38. [CrossRef] 
4. Ballhausen, B.; Kriegeskorte, A.; van Alen, S.; Jung, P.; Köck, R.; Peters, G.; Bischoff, M.; Becker, K. The pathogenicity and host adaptation of livestock-associated MRSA CC398. Vet. Microbiol. 2017, 200, 39-45. [CrossRef]

5. Verkade, E.; Kluytmans, J. Livestock-associated Staphylococcus aureus CC398: Animal reservoirs and human infections. Infect. Genet. Evol. 2014, 21, 523-530. [CrossRef]

6. Atlas, R.M.; Maloy, S. The Future of One Health. Microbiol. Spectr. 2014, 2. [CrossRef]

7. Van Alen, S.; Kaspar, U.; Idelevich, E.A.; Köck, R.; Becker, K. Increase of zinc resistance in German human derived livestockassociated MRSA between 2000 and 2014. Vet. Microbiol. 2018, 214, 7-12. [CrossRef]

8. Argudín, M.A.; Lauzat, B.; Kraushaar, B.; Alba, P.; Agerso, Y.; Cavaco, L.; Butaye, P.; Porrero, M.C.; Battisti, A.; Tenhagen, B.A.; et al. Heavy metal and disinfectant resistance genes among livestock-associated methicillin-resistant Staphylococcus aureus isolates. Vet. Microbiol. 2016, 191, 88-95. [CrossRef] [PubMed]

9. Pal, C.; Asiani, K.; Arya, S.; Rensing, C.; Stekel, D.J.; Larsson, D.G.J.; Hobman, J.L. Metal Resistance and Its Association With Antibiotic Resistance. Adv. Microb. Physiol. 2017, 70, 261-313. [CrossRef] [PubMed]

10. Dierikx, C.M.; Hengeveld, P.D.; Veldman, K.T.; de Haan, A.; van der Voorde, S.; Dop, P.Y.; Bosch, T.; van Duijkeren, E. Ten years later: Still a high prevalence of MRSA in slaughter pigs despite a significant reduction in antimicrobial usage in pigs the Netherlands. J. Antimicrob. Chemother. 2016, 71, 2414-2418. [CrossRef] [PubMed]

11. Becker, K.; Ballhausen, B.; Köck, R.; Kriegeskorte, A. Methicillin resistance in Staphylococcus isolates: The "mec alphabet" with specific consideration of $m e c C$, a mec homolog associated with zoonotic S. aureus lineages. Int. J. Med. Microbiol. 2014, 304, 794-804. [CrossRef] [PubMed]

12. Lakhundi, S.; Zhang, K. Methicillin-Resistant Staphylococcus aureus: Molecular Characterization, Evolution, and Epidemiology. Clin. Microbiol. Rev. 2018, 31. [CrossRef] [PubMed]

13. Monecke, S.; Slickers, P.; Gawlik, D.; Müller, E.; Reissig, A.; Ruppelt-Lorz, A.; Cortez de Jäckel, S.; Feßler, A.T.; Frank, M.; Hotzel, H.; et al. Variability of SCCmec elements in livestock-associated CC398 MRSA. Vet. Microbiol. 2018, 217, 36-46. [CrossRef] [PubMed]

14. Becker, K.; van Alen, S.; Idelevich, E.A.; Schleimer, N.; Seggewiß, J.; Mellmann, A.; Kaspar, U.; Peters, G. Plasmid-encoded transferable mecB-mediated methicillin resistance in Staphylococcus aureus. Emerg. Infect. Dis. 2018, 24, 242-248. [CrossRef] [PubMed]

15. Baba, T.; Kuwahara-Arai, K.; Uchiyama, I.; Takeuchi, F.; Ito, T.; Hiramatsu, K. Complete genome sequence of Macrococcus caseolyticus strain JCSCS5402, reflecting the ancestral genome of the human-pathogenic staphylococci. J. Bacteriol. 2009, 191, 1180-1190. [CrossRef]

16. Tsubakishita, S.; Kuwahara-Arai, K.; Baba, T.; Hiramatsu, K. Staphylococcal cassette chromosome mec-like element in Macrococcus caseolyticus. Antimicrob. Agents Chemother. 2010, 54, 1469-1475. [CrossRef] [PubMed]

17. Schaumburg, F.; Köck, R.; Mellmann, A.; Richter, L.; Hasenberg, F.; Kriegeskorte, A.; Friedrich, A.W.; Gatermann, S.; Peters, G.; von Eiff, C.; et al. Population dynamics among methicillin-resistant Staphylococcus aureus isolates in Germany during a 6-year period. J. Clin. Microbiol. 2012, 50, 3186-3192. [CrossRef]

18. Ballhausen, B.; Jung, P.; Kriegeskorte, A.; Makgotlho, P.E.; Ruffing, U.; von Müller, L.; Köck, R.; Peters, G.; Herrmann, M.; Ziebuhr, W.; et al. LA-MRSA CC398 differ from classical community acquired-MRSA and hospital acquired-MRSA lineages: Functional analysis of infection and colonization processes. Int. J. Med. Microbiol. 2014, 304, 777-786. [CrossRef]

19. Köck, R.; Schaumburg, F.; Mellmann, A.; Koksal, M.; Jurke, A.; Becker, K.; Friedrich, A.W. Livestock-associated methicillinresistant Staphylococcus aureus (MRSA) as causes of human infection and colonization in Germany. PLoS ONE 2013, 8, e55040. [CrossRef]

20. Van Alen, S.; Ballhausen, B.; Peters, G.; Friedrich, A.W.; Mellmann, A.; Köck, R.; Becker, K. In the centre of an epidemic: Fifteen years of LA-MRSA CC398 at the University Hospital Münster. Vet. Microbiol. 2017, 200, 19-24. [CrossRef]

21. Verkade, E.; Bergmans, A.M.; Budding, A.E.; van Belkum, A.; Savelkoul, P.; Buiting, A.G.; Kluytmans, J. Recent emergence of Staphylococcus aureus clonal complex 398 in human blood cultures. PLoS ONE 2012, 7, e41855. [CrossRef] [PubMed]

22. Cuny, C.; Witte, W. MRSA in equine hospitals and its significance for infections in humans. Vet. Microbiol. 2017, 200, 59-64. [CrossRef] [PubMed]

23. Goerge, T.; Lorenz, M.B.; van Alen, S.; Hübner, N.O.; Becker, K.; Köck, R. MRSA colonization and infection among persons with occupational livestock exposure in Europe: Prevalence, preventive options and evidence. Vet. Microbiol. 2017, $200,6-12$. [CrossRef] [PubMed]

24. Omland, Ø.; Hoffmann, L. Occupational acquisition of methicillin-resistant Staphylococcus aureus in humans-A description of MRSA carrier and infected cases from the Region of North Jutland in Denmark. Ann. Agric. Environ. Med. 2012, 19, 637-640.

25. Köck, R.; Siam, K.; Al-Malat, S.; Christmann, J.; Schaumburg, F.; Becker, K.; Friedrich, A.W. Characteristics of hospital patients colonized with livestock-associated meticillin-resistant Staphylococcus aureus (MRSA) CC398 versus other MRSA clones. J. Hosp. Infect. 2011, 79, 292-296. [CrossRef]

26. Cuny, C.; Layer, F.; Hansen, S.; Werner, G.; Witte, W. Nasal Colonization of Humans with Occupational Exposure to Raw Meat and to Raw Meat Products with Methicillin-Susceptible and Methicillin-Resistant Staphylococcus aureus. Toxins 2019, 11, 190. [CrossRef]

27. Beneke, B.; Klees, S.; Stührenberg, B.; Fetsch, A.; Kraushaar, B.; Tenhagen, B.A. Prevalence of methicillin-resistant Staphylococcus aureus in a fresh meat pork production chain. J. Food Prot. 2011, 74, 126-129. [CrossRef] 
28. O’Brien, A.M.; Hanson, B.M.; Farina, S.A.; Wu, J.Y.; Simmering, J.E.; Wardyn, S.E.; Forshey, B.M.; Kulick, M.E.; Wallinga, D.B.; Smith, T.C. MRSA in conventional and alternative retail pork products. PLoS ONE 2012, 7, e30092. [CrossRef]

29. Freitas Ribeiro, L.; Akira Sato, R.; de Souza Pollo, A.; Marques Rossi, G.A.; do Amaral, L.A. Occurrence of Methicillin-Resistant Staphylococcus spp. on Brazilian Dairy Farms that Produce Unpasteurized Cheese. Toxins 2020, 12. [CrossRef]

30. Cuny, C.; Wieler, L.H.; Witte, W. Livestock-Associated MRSA: The Impact on Humans. Antibiotics 2015, 4, 521-543. [CrossRef]

31. Treffon, J.; Fotiadis, S.A.; van Alen, S.; Becker, K.; Kahl, B.C. The Virulence Potential of Livestock-Associated Methicillin-Resistant Staphylococcus aureus Cultured from the Airways of Cystic Fibrosis Patients. Toxins 2020, 12. [CrossRef] [PubMed]

32. Lina, G.; Piémont, Y.; Godail-Gamot, F.; Bes, M.; Peter, M.O.; Gauduchon, V.; Vandenesch, F.; Etienne, J. Involvement of PantonValentine leukocidin-producing Staphylococcus aureus in primary skin infections and pneumonia. Clin. Infect. Dis. 1999, 29, 1128-1132. [CrossRef] [PubMed]

33. Mairi, A.; Touati, A.; Pantel, A.; Zenati, K.; Martinez, A.Y.; Dunyach-Remy, C.; Sotto, A.; Lavigne, J.P. Distribution of Toxinogenic Methicillin-Resistant and Methicillin-Susceptible Staphylococcus aureus from Different Ecological Niches in Algeria. Toxins $2019,11$. [CrossRef] [PubMed]

34. Mairi, A.; Touati, A.; Lavigne, J.P. Methicillin-Resistant Staphylococcus aureus ST80 Clone: A Systematic Review. Toxins 2020, 12. [CrossRef] [PubMed]

35. Scholtzek, A.D.; Hanke, D.; Walther, B.; Eichhorn, I.; Stöckle, S.D.; Klein, K.S.; Gehlen, H.; Lübke-Becker, A.; Schwarz, S.; Feßler, A.T. Molecular Characterization of Equine Staphylococcus aureus Isolates Exhibiting Reduced Oxacillin Susceptibility. Toxins 2019, 11. [CrossRef]

36. Hryniewicz, M.M.; Garbacz, K. Borderline oxacillin-resistant Staphylococcus aureus (BORSA)—A more common problem than expected? J. Med. Microbiol. 2017, 66, 1367-1373. [CrossRef]

37. Raafat, D.; Mrochen, D.M.; Al'Sholui, F.; Heuser, E.; Ryll, R.; Pritchett-Corning, K.R.; Jacob, J.; Walther, B.; Matuschka, F.R.; Richter, D.; et al. Molecular epidemiology of methicillin-susceptible and methicillin-resistant Staphylococcus aureus in wild, captive and laboratory rats: Effect of habitat on the nasal S. aureus population. Toxins 2020, 12. [CrossRef]

38. Himsworth, C.G.; Miller, R.R.; Montoya, V.; Hoang, L.; Romney, M.G.; Al-Rawahi, G.N.; Kerr, T.; Jardine, C.M.; Patrick, D.M.; Tang, P.; et al. Carriage of methicillin-resistant Staphylococcus aureus by wild urban Norway rats (Rattus norvegicus). PLoS ONE 2014, 9, e87983. [CrossRef]

39. Himsworth, C.G.; Patrick, D.M.; Parsons, K.; Feng, A.; Weese, J.S. Methicillin-resistant Staphylococcus pseudintermedius in rats. Emerg. Infect. Dis. 2013, 19, 169-170. [CrossRef]

40. van de Giessen, A.W.; van Santen-Verheuvel, M.G.; Hengeveld, P.D.; Bosch, T.; Broens, E.M.; Reusken, C.B. Occurrence of methicillin-resistant Staphylococcus aureus in rats living on pig farms. Prev. Vet. Med. 2009, 91, 270-273. [CrossRef] 